\title{
PURCHASE AND SALE OF RESOURCE PROPERTIES- THE TECHNIQUES AND REQUIREMENTS
}

\author{
W. GORDON BROWN*
}

\begin{abstract}
The author discusses the techniques and procedures involved in facilitating transactions of resource properties. The lawyer's role in bringing the seller and buyer together, the points of concern in drafting a formal agreement, and the important details in closing the transaction are analyzed. Exhibits of pertinent materials are included at the conclusion of the article.
\end{abstract}

\section{INTRODUCTION}

This discussion of the techniques which may be followed and the requirements which are to be met in the purchase and sale of resource properties is intended to be a description of practical procedures and methods which may be applied and is not a detailed analyses of the numerous intricate legal problems which can arise in these transactions. The procedures and methods dealt with cover the often limited role of the lawyer at the time the prospective seller or buyer is seeking advice on how to locate the most suitable party through to the closing of the transaction-when the lawyer plays a central role.

\section{THE SEARCH FOR THE OTHER SIDE}

The most common point at which the lawyer becomes involved in a purchase and sale transaction is when the purchaser or vendor comes to the lawyer with an arrangement only tentatively made (orally or in casual correspondence), requesting that the arrangement be reduced into a formal written agreement. However, occasionally, a vendor seeks legal advice when searching for a purchaser. If a solicitation is to be made to the public, this usually takes the form of a simple advertisement in trade journals or newspapers stating only that gas properties are for sale ging an address or box number where further inquiry can be directed. There are no pitfalls here except to keep in mind not to take any chances offending securities legislation. For example, if the properties were offered piecemeal, there appears to be some chance of such an advertisement being treated as an offering of securities to the public.

If a solicitation is to be made to a select group, the prospective vendor will seek counsel on the preparation of an invitation to tender. There are two obvious advantages to the vendor in an invitation to tender. First, it results in competitive bidding; secondly, an opportunity is created for the vendor to establish unilaterally certain ground rules for the sale that is ultimately made. In regard to the latter, the matters most often expressly determined in an invitation are the terms of payment, the effective date of the sale, the final date by which the closing must take place and the nature and extent of the warranty to be given.

Most sales of oil and gas properties involve the sale of a particular property or properties in one particular area rather than a sale of all of a party's assets. In these cases, most frequently the prospective purchaser and seller will have made contact directly with each other prior to

- Barrister and Solicitor, Jones, Black \& Company, Calgary, Alberta. 
consulting their respective solicitors. The properties to be sold and the price at which they are to be sold will have been identified and the parties will have some idea as to when the transaction is to be closed. The parties will have agreed upon the barest essentials and, for this reason, it is at this point that a lawyer can serve one of his most useful purposes by asking questions that neither the vendor nor purchaser has considered. If the questions are raised early, it will avoid misunderstandings and the possibility of litigation at a later date. Some of the basic questions for the vendor are:

\section{Has the property been properly identified?}

For example, if it is a working interest being sold, have all the royalties and burdens been disclosed? Is there a depth limitation? Is there a formation excepted out? Are there long term contracts on production in existence? Even such mundane matters as outstanding wellsite clean-up obligations should be discussed. For instance, if the sale is to be closed during winter time, who is to be responsible for the wellsite clean-up which cannot be performed until the following spring?

\section{What is the source of funds?}

Has the purchaser sufficient funds to handle the purchase itself or must the purchaser arrange financing? If so, what part will the vendor play in that arrangement for financing? On the other hand, if the purchaser proposes to manage the acquisition for which it alone has insufficient funds through taking in other parties that will participate in the purchase, the vendor must know the identity of all these parties for the purpose of giving proper notice under rights of first refusal provisions which may be in existence.

\section{Is the purchaser a non-eligible person within the meaning \\ of The Foreign Investment Review Act?}

If so, the solicitor for the vendor should inform his client of the very long delays thus far experienced in obtaining decisions under this legislation and the vendor may well consider seeking a purchaser that is eligible.

The lawyer acting for the purchaser should deal with all the same matters mentioned above which are to be considered by the solicitor for the vendor. This is also the time at which the solicitor for the rpurchaser should make his recommendation as to the precise nature and extent of the title examination to be made. The purchaser's first question will be how long the examination will take; the second will be how much will it cost. While the scope and nature of a title examination can vary considerably depending upon the circumstances, most practitioners would follow these guidelines:

(i) A complete historical search of the lessor's title only as to producing tracts;

(ii) A search of the current mineral title as to freehold tracts and search letters only of Crown tracts as to non-producing properties;

(iii) A complete examination of the lessee's title from inception through to the current holder of both producing and nonproducing properties to determine that the chain of title is complete and intact and that all consents and waivers required 
in the chain have been obtained at the time of each previous conveyance;

(iv) In the case of unitized properties, solicitor's opinions and certificates prepared at the time of the unitization are relied upon and additional searching is confined only to the required updating;

(v) A search at the Conservation Board to determine that assessments are paid to date, at the Sheriff's office for writs, and the Central Registry for liens and chattel mortgages, etc.

If the solicitor involved for the purchaser is in private practice, the purchaser will always be interested in the costs of the title examination and if the purchaser is dealing with his in-house solicitor, management will want to know how much time and how many people will be used in the examination. Until one has advanced well into the title examination, it is difficult to give a reasonably accurate estimate of cost or time that will be involved. When asked to make an estimate at this early stage, the most useful response, and the one that will find a lawyer in the least difficulty at a later date, is to ensure that your estimate is high enough to cover the cost or time. Also emphazize that at this preliminary stage in the title investigation it is necessarily a very rough estimate. If, as the title investigation proceeds, it appears that the estimate is substantially inaccurate one way or the other, it is obviously the responsibility of the lawyer involved to advise his client or employer, as the case may be, of this inaccuracy and provide his revised, and hopefully, more accurate estimate.

\section{One of the knottiest problems-rights of first refusal}

There must be strict compliance with rights of first refusal. A failure to do so means that, following closing of the transaction, the third party holding the right of first refusal may be in a position of being able to upset the transaction or at least having a claim for substantial damages. Obviously, the most satisfactory method of dealing with a right of first refusal is to obtain a waiver from the party holding it. However, in the purchase and sale of oil and gas properties, the lawyers are almost always working under extreme pressure. Time can be frittered away seeking a waiver from the third party who had given some indication that it would likely ge granted. Days are lost awaiting the waiver that does not arrive, until it is finally determined to give formal notice to start the time running. In order to overcome this possible loss of time, it is desirable to seek the waiver and give proper notice in a single instrument at the earliest opportunity. Following this paper, as Exhibit "I", there is set out an example of the form of notice which seeks the waiver, but at the same time starts time running under the right of first refusal provisions.

When giving notice to the party holding the right of first refusal, in order that the notice be adequate to start the time running, it is essential that all information required under the clause be provided. In the current model form of operating agreement sponsored by The Canadian Association of Petroleum Landmen, the right of first refusal clause provides: "The selling party's notice shall contain the terms and conditions of the proplsed assignment, sale or disposition, including the consideration to be received for the subject interest, if applicable, the name of the offering party." In order to be absolutely certain that notice 
has been given of the "... terms and conditions of the proposed assignment, sale or disposition ..." if it is feasible to do so the third party should be provided with a copy of the formal purchase and sale agreement.

If two or more properties are involved in the proposed sale and all of them are not subject to the same right of first refusal, then in order to give proper notice under the right of first refusal provisions there must be an allocation of that portion of the total consideration attributable to the property subject to the right of first refusal. The prospective purchaser may be tempted to allocate an unreasonably high portion of the consideration to the property subject to the right of first refusal in an effort to thwart the exercise of that right. While it would appear to be a difficult proposition to prove, it could be alleged by the third party that the vendor and purchaser have conspired to breach the right of first refusal.

Finally, at this preliminary stage in the negotiations, solicitors for both the vendor and purchaser should determine whether his client or employer, as the case may be, wishes to proceed with the transaction if title fails as to part of the properties by reason of exercise of a right of first refusal or any other reason. Obviously, if the transaction is to proceed as to less than all properties, then a separate consideration must be allocated to each property included in the transaction.

\section{The formal agreement}

Following this paper as Exhibit "II" are typical vendor's warranties, typical purchaser's warranties and typical conditions. In the drafting of the formal agreement, the only area that is frequently contentious as between the lawyers on the two sides is the matter of the vendor's warranties and, in particular, the title warranty. In the example attached, sub-paragraph (b) is in the form frequently identified as a "by, through and under" warranty. What is sometimes asked for by the purchaser and is sometimes given by the vendor is an all embracing warranty that the interests are "valid and subsisting". By necessary implication, this means that the vendor is warranting, not only his predecessors in the lessee's chain, but he is also warranting the lessor's title. Generally, the "by, through and under" warranty is accepted and there is merely a statement to the effect that to the best of the vendor's knowledge, the title being sold is valid and subsisting as set out in the example sub-paragraph (b).

\section{Closing the transaction}

After the formal Buy-Sell Agreement has been negotiated and executed by the parties, the purchaser's lawyer will be conducting his title examination and the vendor's lawyer will be preparing the specific conveyances. If there are many separate pieces of property involved with a variety of chains of title, the only practical method of ensuring that each required document is prepared and that every action prior to the closing has been taken, is to prepare a detailed closing agenda which identifies the documentation. It will show which party is to prepare it and which party is to attend the registration if applicable. The closing agenda should be prepared as soon as possible following the execution of the Buy-Sell Agreement in order that the responsibilities for document preparation and any necessary action is known by the parties well in advance of closing. Following the paper as Exhibit "III" is a draft form 
of closing agenda which involves, not only the purchaser and vendor, but also a lending institution which is financing the transaction.

The objective of the solicitors for both parties is to close the transaction carefully, smoothly and quickly. The most useful action to achieve these goals is for the lawyers to meet together a couple of days prior to the closing date to conduct a "dry run". Any lack of documentation or failure of action will appear then and hopefully time would be available to remedy the defects prior to the closing date.

In order that the purchase price monies can be released on the closing date, pre-registration of registerable documents may be provided for. Attached as Exhibit "IV" is a typical form of this clause. Prior to the closing, the parties should consider the disposition that is to be made of the purchase price. If the vendor is a non-resident within the meaning of The Income Tax Act, a certificate will have to be obtained under Section 116 of the Act. If the properties are encumbered and these are to be discharged by use of a portion of the purchase price, the amount required to effect a discharge should be determined in advance together with a per diem rate of interest. Either the holder of the encumbrance should be in attendance at the closing to deliver the discharge of the encumbrance or the discharge should have been delivered earlier in trust against payment.

If the preliminary steps mentioned above are taken prior to closing, a pressure-packed two hours with frazzled tempers and dignity can be avoided and the closing can be a somewhat relaxed period. 


\section{EXHIBIT I}

\section{WAIVER OF RIGHT OF FIRST REFUSAL}

\section{(LETTERHEAD OF VENDOR)}

Addressed to third party holding right of first refusal

Re: The Area subject to Right of First Refusal

The third party and Vendor are parties to an agreement dated April 1, 1974 ("the Operating Agreement") relating to the above area ("the subject lands").

As part of the transaction involving the sale of other lands, the Vendor is proposing to sell to the Purchaser all of the interest of the Vendor in those lands which are jointly held by the Vendor and the third party in the above mentioned area. The consideration for the purchase of this interest is $\$$ sale to be effective as of December 1, 1974. , Canadian funds, with the

We request your consent and waiver of the right of first refusal under Clause of the Operating Agreement by signing and returning to us one counterpart of this letter. As we are anxious to complete the sale, we ask that you be good enough to execute the waiver and return it to us as soon as possible. If you are unwilling to do so, please accept this as notice under the Operating Agreement in order to commence the fifteen day period in which you must elect to purchase.

\section{Yours very truly \\ Vendor}

Consent and Waiver granted

this day of December, 1974

Third Party

\section{EXHIBIT II}

\section{TYPICAL VENDOR'S WARRANTIES}

Seller represents, warrants and agrees to and with Buyer that:

(a) This Agreement has been duly authorized, executed and delivered by Seller and constitutes the valid and binding agreement of Seller in accordance with its terms;

(b) The Interests are free and clear of all liens, encumbrances, burdens and defects of title created by, through or under the Seller excepting only those specifically described in Exhibit "A" hereto and Seller is not aware of any other liens, encumbrances or title defects relating to or affecting the Interests and to the best of the knowledge of the Seller, the Interests are valid and subsisting;

(c) Seller has good right and lawful authority to sell and convey the Interests as contemplated by this Agreement; 
(d) Seller has received no notice of default under any agreement relating to the Interests to which it is a party or by which it is bound, or with respect to any statute, order, writ, injunction or decree of any governmental agency or any court and is aware of no defaults of which a prudent operator would be aware;

(e) All royalties, rentals and deposits due under the Leases and payable by the Seller have been properly and timely paid;

(f) Seller is not obligated, by virtue of a prepayment arrangement under any contract for the sale of hydrocarbons and containing a "take or pay" or similar provision, of a production payment or of any other arrangement, to deliver hydrocarbons produced from the Interests at some future time without then or thereafter receiving full payment therefor;

(g) All ad valorem, property, production, severance and similar taxes and assessments based on or measured by the ownership of property of the production of hydrocarbons or the receipt of proceeds therefrom on the Interests payable by Seller for 1974 and all prior years have been properly paid;

(h) Seller has incurred no obligation or liability, contingent or otherwise, for brokers' or finders' fees in respect of this transaction for which Buyer shall have any obligation or liability;

(i) Between the date hereof and Closing Date to the extent it is under its reasonable control, Seller:

(i) shall cause the Interest to be developed, maintained and operated in a good and workmanlike manner, provided, however, that Seller shall not commence or permit to be commenced operations for the drilling of any new well (other than the Test Well currently being drilled as described in clause 2(d) hereof) or the redrilling of any existing well on the Interests after the date of this Agreement and prior to the Closing without the prior written consent of Buyer;

(ii) will maintain insurance now in force with respect to the Interests;

(iv) will make or cause to be made all payments required to be under the Leases and will perform and comply with all of the covenants and conditions contained in the Leases and all other agreements relating to the Interests;

(v) will not without the prior written consent of Buyer enter into any new agreements or commitments (other than in the ordinary course of business) with respect to the Interests which extend beyond the Closing, and will not make any expenditures on any one property included in the Interests in excess of Five Thousand Dollars $(\$ 5,000.00)$, (other than the Well Expense and other costs and expenses described in clauses $2(\mathrm{~d})$ and 14 hereof), and will not abandon any well located on the Interests, nor release or abandon all or any portion of any of the Leases and will not modify or terminate any of the agreements relating to the Interests and will not sell or otherwise dispose of any of the Interests other than personal property which is replaced by equivalent property or consumed in the operation of the Interests; 
(vi) shall maintain and preserve his organization for operating the Interests until the Closing; and

(vii) shall exercise all due diligence in safeguarding and maintaining secure all engineering, geological and geophysical data, reports and maps, and all other confidential data in its possession, relating to the Interests;

(j) No suit, action or other proceeding is pending or threatened before any court or governmental agency which might result in impairment or loss of Seller's title to the Interests and Seller hereby indemnifies and agrees to hold harmless the Buyer against any loss or cost arising out of any such claim;

(k) Seller shall use his best efforts to cause all insurance coverage maintained under (i) above, which Buyer wishes transferred to it, to be transferred to Buyer with proper adjustments for unused premiums;

(1) All applicable laws, regulations and orders of all governmental agencies having jurisdiction over the Interests have been and shall continue to be complied with by Seller until the Closing;

(m) At all times prior to the Closing, if this Agreement shall not have first been terminated, Buyer and its employees and agents shall have access to the Interests;

(n) Seller has made available to Buyer, its employees and agents, all documents and information materially pertaining to or affecting the Interests insofar as such documents and information are known to Seller, to its officers and employees, and are in Seller's control; and based upon other reasonable inquiry and search by Seller's officers and employees, to Seller's knowledge he has not withheld from Buyer, its employees or agents, any material documents or information reasonably required to make not misleading those documents and information so made available by Seller to Buyer.

\section{TYPICAL PURCHASER'S WARRANTIES}

Buyer represents, warrants and agrees to and with Seller that:

(a) Purchaser is a corporation duly organized and existing under the laws of the Province of Ontario, and is duly authorized or shall prior to Closing become duly authorized to conduct business in the jurisdictions in which registrable conveyances of the Interests are to be recorded;

(b) This Agreement has been duly authorized, executed and delivered by Buyer and constitutes the valid and binding agreement of Buyer in Accordance with its terms;

(c) Buyer has good right and lawful authority to purchase the Interests as contemplated by this Agreement;

(d) Buyer shall exercise all due diligence in safeguarding and maintaining secure all engineering, geological and geophysical data, reports and maps, and all other confidential data in its possession, relating to the Interests, and if this Agreement is terminated for any reason, Buyer shall promptly return to Seller all such data, reports and maps and keep all information obtained therefrom strictly confidential. 


\section{TYPICAL CONDITIONS}

The obligations of Buyer under this Agreement are subject, in the discretion of Buyer, to the satisfaction at or prior to the Closing of the following conditions:

(a) All representations and warranties of Seller contained in this Agreement shall be true in all material respects at and as of the Closing as if such representations and warranties were made at and as of the Closing, and Seller shall have performed and satisfied all agreements required by this Agreement to be performed and satisfied by Seller prior to or at the Closing;

(b) Seller has good, absolute and marketable title to the Interests, free and clear of all liens, encumbrances, burdens and defects of title except as set forth herein;

(c) The Leases are in full force and effect and are valid and subsisting documents covering the entire estates which they purport to cover;

(d) All royalties, rentals and deposits due under the Leases have been properly and timely paid and all conditions necessary to keep the Leases in force have been fully performed;

(e) All ad valorem, property, production severance and similar taxes and assessments based on or measured by the ownership of property or the production of hydrocarbons or the receipt of proceeds therefrom on the Interests for 1974 and all prior years have been properly paid;

(f) All valid laws, regulations and orders of all governmental agencies having jurisdiction over the Interests have been and shall continue to be complied with by Seller until the Closing;

(g) The Interests shall be subject to an Operating Agreement binding all working interest owners therein which shall be satisfactory in form and substance to the Buyer in the Buyer's reasonable discretion;

(h) Seller shall at Seller's expense obtain and deliver to Buyer at Closing the approval of the Public Utilities Board pursuant to the requirements of Section 24(1)(g) of the Gas Utilities Act of Alberta in respect of the herein described sale of the Interests to the Buyer;

The conditions of this clause are inserted for Buyer's exclusive benefit and may be waived in whole or in part by it at any time. If any of the said conditions are not complied with or performed to Buyer's reasonable satisfaction on or before the Closing Date or compliance or performance is not waived by Buyer, then Buyer may terminate this Agreement by notice in writing to Seller without liability to either party. 
EXHIBIT III

TYPICAL CLOSING MEMORANDUM

Sale-Vendor to Purchaser and Loan Agreement and Mortgage Purchaser with Bank

Time and Place of Closing

Definitions

The following designations used in this memorandum have the meanings set forth below:

For Vendor:

\section{Present}

For Purchaser:

For Bank:

PART I

VENDOR TO PURCHASER CLOSING

Document

1. Sale Agreement

2. General Conveyances

(a) P \& NG Rights Conveyance

(b) General Indenture

(c) Bill of Sale

3. Statutory Transfers of Crown Leases, Vendor to Trustee

4. Prescribed form of Assignment of PanCanadian Leases from Vendor to Purchaser

5. Opinion of Vendor's Solicitors

6. General Reconveyances

(a) P \& NG Rights Conveyance

(b) General Indenture

(c) Bill of Sale

7. Form of Statutory Re-transfers of Crown Leases, Trustee to Vendor

8. Letter from the Bank to the Trustee authorizing execution of item 7 by Trustee

$\begin{array}{ccc}\text { Copies } & \begin{array}{c}\text { Delivered } \\ \text { By }\end{array} & \begin{array}{c}\text { Delivered } \\ \text { To }\end{array} \\ 2 & - & - \\ 2 & \text { Vendor } & \text { Purchaser }\end{array}$

4 Vendor Purchaser's

Solicitors

4 Vendor Purchaser's

Solicitors

3 Vendor's Purchaser

Solicitors Bank

Purchaser's

Solicitors

2 Purchaser Vendor's

Solicitors

4 for delivery Purchaser's by Trustee Solicitors

3 Bank
Vendor's Solicitors Purchaser's Solicitors Purchaser 
9. Prescribed form of Reassignment of PanCanadian Leases

3 Purchaser

Vendor's from Purchaser to Vendor

10. Letter from Purchaser's Solicitors to Vendor's Solicitors delivering items 6,7 and 9

11. Opinion from Purchaser's Solicitors to Purchaser on purchased properties

12. Public Utilities Board Order approving sale (previously delivered)

13. Cheque of Purchaser to Vendor for $\$$ representing part payment of purchase price $3 \quad \begin{array}{r}\text { Purchaser's } \\ \text { Solicitors }\end{array}$

3 Purchaser's Solicitors

\section{Vendor's} Solicitors

1 Purchaser
Solicitors

Vendor's

Solicitors

Bank

Purchaser

Purchaser

Bank

Bank's Solicitors

Purchaser's Solicitors

Vendor

\section{PART II}

LOAN BY BANK TO PURCHASER CLOSING

\section{Document}

14. Purchaser corporate documents:

(a) Directors Resolution

(b) Incorporation Documents

(c) Certificate of Good Standing

(d) Certificate re taxes

(e) Certificate of Incumbency

(f) Certificate pursuant to Loan Agreement

15. Loan Agreement

16. Mortgage

17. Note

18. Opinion of Purchaser's Solicitors pursuant to Loan Agreement

$\begin{array}{ccc}\text { Copies } & \begin{array}{c}\text { Delivered } \\ \text { By }\end{array} & \begin{array}{c}\text { Delivered } \\ \text { To }\end{array} \\ 3 & \text { Purchaser } & \begin{array}{l}\text { Bank } \\ \text { Bank's } \\ \text { Solicitors } \\ \end{array} \\ & & \begin{array}{c}\text { Purchaser's } \\ \text { Solicitors }\end{array}\end{array}$

5 Purchaser Bank

20 Purchaser

1 Purchaser

3 Purchaser's Solicitors
Bank

Purchaser

Purchaser's

Solicitors

Bank's Solicitors

Purchaser's

Solicitors

Bank

Bank's

Solicitors

Bank (original)

Bank's

Solicitors

(copies)

Purchaser's

Solicitors

Bank

Bank's

Solicitors

Purchaser 
19. Opinion of Bank's Solicitors

20. Issuance of deposit receipt by Bank to Vendor's Solicitors

21. Letter by Bank to Vendor's Solicitors and Purchaser (to be countersigned by Vendor's Solicitors and Purchaser) re disposition of deposited funds

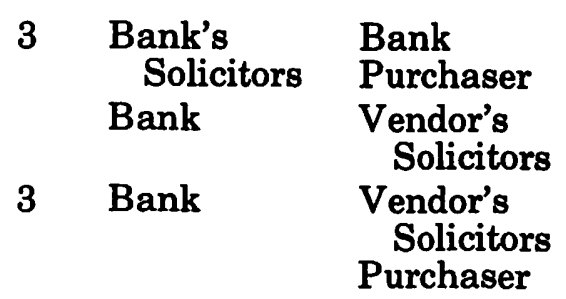

\section{PART III}

\section{MATTERS TO BE CONCLUDED IMMEDIATELY AFTER CLOSING}

A. Execution of the Mortgage and conveyances by Trustee and filing and/or registration thereof.

1. Trustee to execute 10 counterparts of the Mortgage and deliver 9 to Purchaser's Solicitors.

2. Purchaser's Solicitors to distribute counterparts of the fully executed Mortgage as follows:

1 to Purchaser

1 to Bank

1 to Bank's Solicitors.

3. Purchaser's Solicitors to arrange for the filing and/or registration of the Mortgage in:

(i) the office of the Registrar of Companies pursuant to The Companies Act (Alberta);

(ii) as a caveat in the appropriate Government Land Titles Office in the Province of Alberta;

(iii) in the Department of Mines and Minerals (Alberta); and

(iv) in other appropriate offices.

4. Purchaser's Solicitors to make application to Public Utilities Board for Order approving Mortgage.

5. Purchaser's Solicitors to register conveyances of Crown Leases.

6. Purchaser's Solicitors shall give telephone advice followed by letters of the completion of the registration and/or filing of the Mortgage, issuance of Public Utilities Board Order and release of their opinions to:

(i) the Trustee;

(ii) the Bank;

(iii) Purchaser;

(iv) Bank's Solicitors.

7. Bank's Solicitors shall release their opinion and give notice of the effective date thereof to each of:

(i) the Bank;

(ii) the Trustee;

(iii) Purchaser;

(iv) Purchaser's Solicitors.

8. The Bank to dispose of deposit in accordance with the direction previously given pursuant to item 21 . 


\section{PART IV}

\section{ACTION TO BE TAKEN AFTER ADVANCE OF FUNDS}

A. Notice of the Assignment to the Trustee to be given to purchaser of, and holders of proceeds from, production and copies of the Mortgage to be furnished to such purchasers and holders.

B. Filing and registration data and copies of Public Utilities Board Order to be furnished by Purchaser's Solicitors to all parties as to filing and/or registration of the Mortgage and any other instruments in appropriate Governmental offices in Canada.

C. Conformed copies of the printed documents will be distributed as follows:

1. To the Bank:

10 Loan Agreement

10 Mortgage.

2. To the Purchaser.

5 Loan Agreement

20 Mortgage.

3. To the Trustee:

5 Loan Agreement

5 Mortgage.

4. To the Purchaser's Solicitors:

2 Loan Agreement

2 Mortgage.

5. To the Bank's Solicitors:

2 Loan Agreement

2 Mortgage.

PART V

\section{LIST OF DOCUMENTS AND CLOSING PAPERS}

1. Sale Agreement

2. General Conveyance
(a) P \& NG Rights Conveyance
(b) General Indenture
(c) Bill of Sale

3. Statutory Transfers of Crown Leases, Vendor to Trustee

4. Prescribed form of Assignment of PanCanadian Leases from Vendor to Purchaser

5. Opinion of Vendor's Solicitors

6. General Reconveyances
(a) P \& NG Rights Conveyance
(b) General Indenture
(c) Bill of Sale

7. Form of Statutory Re-transfers of Crown Leases, Trustee to Vendor

8. Letter from the Bank to the Trustee authorizing execution of item 7 by Trustee

9. Prescribed form of Reassignment of PanCanadian Leases from Purchaser to Vendor 
10. Letter from Purchaser's Solicitors to Vendor's Solicitors delivering items 6,7 and 9

11. Opinion from Purchaser's Solicitors to Purchaser on purchased properties

12. Loan Agreement

13. Note

14. Mortgage

15. Resolutions of the Board of Directors of the Purchaser certified by the Secretary-Treasurer as of the closing date

16. Resolutions or other evidence of authority of the Corporate Trustee to execute, deliver and accept the various instruments to be so executed, delivered and accepted by it pursuant to the Loan Agreement certified by the Secretary as of the closing date

17. Certificate of Incorporation, Memorandum and Articles of Association of the Purchaser and all amendments thereto, certified by the Secretary-Treasurer of the Purchaser as of the closing date as being a true and complete copy

18. Certificate of the Registrar of Companies (Alberta) as to the good standing of the Purchaser in the Province of Alberta, Canada, dated as near as possible to the date of closing

19. Certificate of the Secretary-Treasurer of the Purchaser as to payment of National and Provincial taxes in Canada, dated the date of closing

20. Certificate of the Secretary-Treasurer of the Purchaser showing incumbency and specimen signatures of officers of the Company, dated the date of closing

21. Certificate dated as of the closing date of the Purchaser to the Bank pursuant to Section 8C of the Loan Agreement

22. Deposit receipt

23. Letter by Bank to Vendor's Solicitors and Purchaser re disposition of funds

24. Opinion of Purchaser's Solicitors pursuant to Sections $8 \mathrm{D}$ and $\mathrm{E}$ of the Loan Agreement

25. Letter from Purchaser's Solicitors releasing opinion

26. Opinion of Bank's Solicitors pursuant to Section $8 F$ of the Loan Agreement

27. Letter from Bank's Solicitors releasing opinion

28. Notices to purchasers of, and holders of proceeds from, production accruing to the Mortgaged Property

\section{EXHIBIT IV}

\section{TYPICAL FORM OF PRE-REGISTRATION CLAUSE}

All those conveyances, assignments, transfers, bills of sale and other instruments conveying the Interests to Buyer which are subject to recording in offices of public record shall be in proper recordable form. 
All of such instruments shall be executed by the Seller prior to the Closing Date and shall be delivered to Messrs. with authority to immediately effect all recordings required by such solicitors with a view to the completion of all required registrations in offices of public record prior to the Closing Date.

The Closing shall be held at 10:00 a.m. on the day of 1974 , at the offices of other date or place as the parties agree, provided however, that if at the Closing, all conditions of this Agreement have not been fulfilled or waived by the party having discretion to waive such conditions, then unless both parties by mutual agreement in writing agree to extend the Closing, this Agreement shall terminate on that date, and upon such termination, both parties shall be released from all further obligations hereunder. If this Agreement is so terminated or terminated under any other provision of this Agreement, Buyer shall return to Seller all of the items which Seller has delivered to Buyer under the terms of this Agreement. 